\title{
TEACHING PRACTICE FOR THE 21ST CENTURY: CHALLENGES AND PROSPECTS FOR TEACHER EDUCATION IN UZBEKISTAN
}

(CAzimbaeva R., ORCID: 0000-0003-4762-3638, Tashkent Institute of Finance, Tashkent,Uzbekistan,azimbayevarano@gmail.com

\section{ПЕДАГОГИЧЕСКАЯ ПРАКТИКА 21 ВЕКА: ПРОБЛЕМЫ И ПЕРСПЕКТИВЫ ПЕДАГОГИЧЕСКОГО ОБРАЗОВАНИЯ В УЗБЕКИСТАНЕ}

\section{(C)Азимбаева P. Ю., ORCID: 0000-0003-4762-3638, Ташкентский финансовый институт, 2. Ташкент, Узбекистан, azimbayevarano@gmail.com}

Abstract. The paper considers the interrelation of the problem of maintenance of quality of higher education and professionalism of the teacher. The result of the research made it possible to prove the value of professionally important qualities of the teacher in the improvement of the quality of educational services in the conditions of competitiveness of higher education system. Qualitative foreign teaching is one of the most important key characteristics defining the professional competence of a higher school graduate as a whole and is considered from the point of view of systemacy, of integral content, of teaching technologies, of methods of control and assessment of the results.

Аннотащия. В статье рассматривается взаимосвязь проблемы обеспечения качества высшего образования и профессионализма педагога в процессе языкового обучения. В результате исследования обосновано значение профессионально важных качеств педагога в повышении качества образовательных услуг в условиях конкурентоспособности системы высшего образования. Качественное иноязычное образование - одна из важнейших, ключевых характеристик, определяющих профессионализм выпускника вуза, высшего образования в целом. Она рассматривается с позиций системности, целостности содержания, технологий обучения, методов контроля и оценки результатов.

Keywords: quality of education, professionalism of the teacher of the system of higher education, the teaching of foreign languages, Common European Framework of Reference, facilitator, autonomous learners, foreign language, knowledge quality, system approach, curricula modernization, traditional and interactive education.

Ключевые слова: качество образования, профессионализм педагога системы высшего образования, иностранный язык, качество знаний, системный подход, модернизация учебных программ, традиционное и интерактивное обучение.

21 st century - the century of the global development of new technologies, which based on highly-educated population - a vector of new ideas and solutions on urgent economic issues. Today, the competition winner is the one who has highly developed human capital [1].

In the fast-changing world of the early 21 st century higher education is also changing. As part of the changes, the role of universities and education will also be different both in the educational system and in society. Together with them, the role of teachers will also change. If we aim to have a 
closer look at the characteristic features of the changes, we have to examine what they are. What everybody can see at first sight is that not only our society but also our educational system went through relevant changes.

Universities used to be the source of knowledge, a place where students were educated more or less without parental control. Universities used to prepare learners for their future career. Thus, teaching should be up to the International Standard Classification of Education. Together with the changes, new expectations appeared towards our educational institutions. Nowadays universities need to teach their learners how to gain information and how to select and use them. This happens so quickly that students learn how to use the Internet together with their teachers. Parents are involved in decision-making so they take part in the life of the university [2].

The changes that took place in our educational system have changed the roles of teachers, too. In the past teachers used to be the major source of knowledge, the leader and educator of their students' life. Teachers would organize after-university activities. They used to be the authority in the class and often took over the role of parents. Nowadays, teachers provide information and show their students how to tackle them. Although they are still considered to be a kind of leader in the class, they can be thought of as facilitators in the learning process. They are supporters rather than educators and also advisors towards parents.

If we focus on the teaching process, we still realize that there are a great number of changes in this field as well, and all of them have an influence on the role of teachers. First of all, teachers in modern classrooms are no longer lecturers, they are facilitators, their main task is to set goals and organize the learning process accordingly. Then, in the past, teachers used to follow a syllabus which was compulsory for them. Nowadays, teachers have the independence to choose the teaching materials, make up a syllabus of their own and teach their students so that they can perform well both at examinations and in life. Curriculum design is a task teacher have to be prepared for, although the present generation of teachers has been growing into making up syllabi for years [3].

Another difference between the past and present tasks of teachers is represented by the technical background they need to be able to use and handle effectively (computer, photocopier, powerpoint, projectors). Instead of teaching chalk face, they need to be an information technology expert, a technician master.

One of the biggest challenges for teachers is that their role in the university management has also changed. The university needs them as individuals, who can make decisions and cope with the stress of the changing world of universities. At the same time, teachers need to be able to work in teams, co-operate with colleagues and parents. "A future teacher of foreign language must not only acquire the language independently, understand its structure deeply and correctly from a linguistic point of view, but she or he should know the sides of foreign languages which draw together or differ this language from pupils' mother tongue" [4].

In our view, teacher education - rather than teacher training - needs to change in the near future. Some experts say it is too late to begin the changes, as we need new competencies in teaching right now. However, if teacher education in Uzbekistan follows its best tradition, and it remains practical, flexible and student-centered, there is a hope that the next generation of learners will get the support and skills they need in life during their studying years from their own teachers.

The need of a generation of teachers who aim to develop learners instead of teaching them, who help their students to become independent, who provide students with motivation and interest for life-long learning and urge them to become autonomous learners, is essential in the education of the future [5].

Today, in the Republic of Uzbekistan great attention is given to the radical reorganization of the educational system that will give an opportunity to raise it to the level of modern standards. In 
order to realize the aims and tasks put forward by the Law of the Republic of Uzbekistan "On Education" and the "National Programme of Personnel Training" the complex system of reorganizing the structure and the content of personal training, proceeding from perspectives of the social, economic development of the society, contemporary achievements of science, culture, technique and technology are being created in the country.

The National Programme for Personnel Training is being implemented in the country step by step. Within the framework of this Programme the system of continuous education is being developed, a system which starts with the pre-school provision. The material and technical base of the education sector is strengthening, basic textbooks in the languages of peoples, living in the country are being published, the physical learning environment is improved, modern information technology is being used in the process of education. New approaches in the system of education also influenced on the learning and teaching of foreign languages, as language is the major factor of a person's development.

The main of them is that the compliance of learning programmes and curricula with international standards will require not simply "further improvement" but gradual, but radical reform in the entire education system and education philosophy which is hard to achieve by simply expanding the relevant administrative divisions of ministries and the testing center. The widely accepted language standards in the world are the Common European Framework of Reference, which distinguishes six levels of fluency of any language based on a broad range of criteria bearing mostly practical and communicative nature. All language skills in this system are presented in the form of statements describing a certain skill. For example, a student of the B1 level should be able to communicate in most situations that may arise in a country whose language he or she is learning. All curricular, programmes, methods, materials and tests should aim to develop such skill depending on a level set at a certain educational establishment or in a country for certain students. In other words, the current system of marking students' performance is usually tied to norms that are conventionally and subjectively set by a teacher and it should be replaced by an objective, verifiable, fair and unambiguous system [6].

The center is responsible for great deal of work, like carrying out scientific researches directed on working out and introducing of innovative techniques of teaching foreign languages to students at all grades of continuous education; developing educational standards on learning foreign languages; maintaining methodological support for educational institutions, preparing teachers and experts in the field of foreign language teaching, implementing modern methods of teaching foreign languages, monitoring the realization of requirements of the international standards of teaching foreign languages according to "Common European Framework of References: learning, teaching, assessing" [7].

The introduction of foreign language teaching in first forms should not be just by changing standards of marking and adopting a new curriculum. A huge number of mutually complementary learning materials should be devised and produced, including audio, video and electronic resources. Finally, the most important is to train an army of teachers who are not just fluent in a foreign language but are also proficient in modern methods of teaching it, which brings up the issue of education philosophy, or even mentality [8].

In order to reach the aim and fulfil tasks put forward before education every teacher, every researcher in the field of methodology should think of finding the effective ways of teaching students. As a researcher, in learning foreign languages we are suggesting and experimenting with the use of modular technology with the learners of universities in our country.

Modern education is based on democratic and liberal principles: students should not be forced, but motivated. A teacher is not a tyrant who strictly maintains order in class, checks 
homework and in deathly silence explains grammar rules, but is an older friend who can help, support and interest a student and ideally only directs his or her conscientious desire to learn the language. Not only should a teacher be able to explain grammar and vocabulary but organize work in groups and pairs to enable students to communicate in a foreign language to solve problems without mindless repetition of words written on the blackboard [9].

We have to change such an attitude to learning in the root if we want to bring our standards of foreign language learning to international levels in the near future. Naturally, in order to conduct a large-scale reform, we need not only teachers but also managers who are capable of solving longterm problems. We hope that this way of learning helps us prepare a good language learner, who is able to find their own way of learning, can organize information about the language, make their own opportunities for practice, very language according to the situation and make intelligent guesses. In conclusion, we'd like to say that we should prepare in our country the methods of intensive foreign language learning based on our national peculiarities. Only in this way we can provide our students with all the necessary conditions for access to this amazing world of foreign languages.

What is important is that language teacher should be ready to evaluate their teaching and get feedback from their students. If they did not achieve the result they had aimed at, they must be ready to change their teaching methodology and techniques. A certain amount of openness in the language teacher can really do wonders. They should ask themselves how to make English language teaching and learning more enjoyable and how to enhance students learning and maximize their productivity. A teacher of English who does not laugh and allow their students to laugh in the English class cannot be a successful teacher of the language.

\section{References:}

1. Borthwick, A., \& Pierson, M. (2008). Transforming Classroom Practice: Professional Development Strategies in Educational Technology. Washington. D.C, ISTE.

2. Collins, A., \& Halverson, R. (2009). Rethinking education in the age of technology. New York, Teachers College Press.

3. Johnson, L., Adams, S., Haywood, K. (2011). The NMC Horizon Report: 2011 K-12 Edition. Austin: The New Media Consortium.

4. Leke-ateh, B. A., Assan, T. E. B., \& Debeila, J. (2013). Teaching practice for the 21st century: Challenges and prospects for teacher education in the North-West Province, South Africa. Journal of Social Sciences, 37(3), 279-291. https://doi.org/10.1080/09718923.2013.11893226.

5. Lieberman, A., \& Pointer Mace, D. (2010). Making practice public: Teacher learning in the 21st century. Journal of teacher education, 61(1-2), 77-88. https://doi.org/10.1177/0022487109347319.

6. Yost, D. S., Sentner, S. M., \& Forlenza-Bailey, A. (2000). An examination of the construct of critical reflection: Implications for teacher education programming in the 21 st century. Journal of teacher education, 51(1), 39-49. https://doi.org/10.1177/002248710005100105

7. Hudson, D. M., \& Roberts, A. M. (2019). Foundations of Christian thought and practice: a model for replacing Old and New Testament surveys with an innovative approach to teaching religion in 21st century colleges and universities. Journal of Religious Education, 1-16.

8. Forzani, F. M. (2014). Understanding "core practices" and "practice-based" teacher education: Learning from the past. Journal of Teacher Education, 65(4), 357-368. https://doi.org/10.1177/0022487114533800

9. Singh P., Allen J., \& Rowan L. (2019). Quality teaching: standards, professionalism, practices. https://doi.org/10.1080/1359866X.2019.1557925. 


\section{Список литературы:}

1. Borthwick A., Pierson M. Transforming Classroom Practice: Professional Development Strategies in Educational Technology. Washington. D.C: ISTE. 2008.

2. Collins A., Halverson R. Rethinking education in the age of technology. New York: Teachers College Press. 2009.

3. Johnson L., Adams S., Haywood K. The NMC Horizon Report: 2011 K-12 Edition. Austin: The New Media Consortium. 2011.

4. Leke-ateh B. A., Assan T. E. B., Debeila J. Teaching practice for the 21 st century: Challenges and prospects for teacher education in the North-West Province, South Africa // Journal of Social Sciences. 2013. V. 37. №3. P. 279-291. https://doi.org/10.1080/09718923.2013.11893226.

5. Lieberman A., Pointer Mace D. Making practice public: Teacher learning in the 21st century // Journal of teacher education. 2010. V. 61. №1-2. P. 77-88. https://doi.org/10.1177/0022487109347319.

6. Yost D. S., Sentner S. M., Forlenza-Bailey A. An examination of the construct of critical reflection: Implications for teacher education programming in the 21 st century // Journal of teacher education. 2000. V. 51. №1. P. 39-49. https://doi.org/10.1177/002248710005100105.

7. Hudson D. M., Roberts A. M. Foundations of Christian thought and practice: a model for replacing Old and New Testament surveys with an innovative approach to teaching religion in 21st century colleges and universities // Journal of Religious Education. 2019. P. 1-16.

8. Forzani F. M. Understanding "core practices" and "practice-based" teacher education: Learning from the past // Journal of Teacher Education. 2014. V. 65. №4. P. 357-368. https://doi.org/10.1177/0022487114533800.

9. Singh P., Allen J., Rowan L. Quality teaching: standards, professionalism, practices. 2019. https://doi.org/10.1080/1359866X.2019.1557925.

Работа поступила

в редакциию 04.03.2019 г.
Принята к публикациии

11.03.2019 2.

Ссылка для цичтирования:

Azimbaeva R. Teaching Practice for the 21st Century: Challenges and Prospects for Teacher Education in Uzbekistan // Бюллетень науки и практики. 2019. Т. 5. №4. С. 457-461. https://doi.org/10.33619/2414-2948/41/67.

Cite as (APA):

Azimbaeva, R. (2019). Teaching Practice for the 21st Century: Challenges and Prospects for Teacher Education in Uzbekistan. Bulletin of Science and Practice, 5(4), 457-461. https://doi.org/10.33619/2414-2948/41/67. 